\title{
PERSISTENT UPPER RESPIRATORY DISEASES IN CHILDREN: ROLE OF GASTROESOPHAGEAL REFLUX STUDIED USING INTRALUMINAL IMPEDANCE AND PH
}

\author{
Renata Cudejko ${ }^{1,2}$, Marcin Dziekiewicz ${ }^{3}$, Aleksandra Banaszkiewicz ${ }^{3}$, Henryk Skarzynski ${ }^{1}$, \\ Andrzej Radzikowski \\ ${ }^{1}$ Institute of Physiology and Pathology of Hearing, Mokra 17 Kajetany, 05-830 Nadarzyn, Poland \\ ${ }^{2}$ Opole Center of Hearing and Speech "MEDINCUS", Opole, Poland \\ ${ }^{3}$ Department of Pediatric Gastroenterology and Nutrition, The Medical University of Warsaw, Dzialdowska 1, \\ 01-184 Warsaw, Poland
}

Corresponding author: Renata Cudejko, ul. Mokra 17, 05-830 Nadarzyn/k. Warsaw, Poland, Tel/fax: +48 7755111 70, e-mail: r.cudejko@csim.pl and Opole Center of Hearing and Speech "MEDINCUS", 122 B Wiejska Str., 45-303 Opole, Poland

\begin{abstract}
Background: A variety of signs and symptoms of otolaryngological complaints have been attributed to gastroesophageal reflux disease (GERD). However, proof of such an association is spare. Recent studies suggest that in some cases GERD may be connected with upper respiratory diseases in children, and this paper explores the connection. The aim of the study was to estimate the incidence of GERD among children with persistent upper respiratory disease by inserting an electrode into the esophagus. Reflux can be detected as changes in intraluminal resistance brought on by liquid inside the esophagus, and $\mathrm{pH}$ measurements can be used to classify the reflux as acidic or nonacidic.
\end{abstract}

\begin{abstract}
Material and Methods: This was a multicenter, prospective study of children (4-11.5 years old) with persistent upper respiratory disease. Chronic diseases such as allergy, asthma, cystic fibrosis, or congenital anomalies were excluded. The diagnosis of chronic upper tract disease was made by a single laryngologist. All children underwent a 24-hour multichannel intraluminal impedance and $\mathrm{pH}(\mathrm{MII}-\mathrm{pH})$ study. The diagnosis of GERD was made with BioVIEW analysis software after manual review by a single investigator.
\end{abstract}

Results: Exactly 31 consecutive patients (17 boys, 14 girls, mean age 6.8 years) were enrolled in the study. A diagnosis of GERD was made in $11 / 31$ (35\%) patients. A total of 1172 reflux episodes were detected by MII-pH, and $759(65 \%)$ of them were acid, 413 (35\%) were nonacid. The most common symptoms were mouth breathing (28/31), snoring (22/31), fetor ex ore (13/31), hawking (4/11), and apnea (2/11). None of the patients declared gastroenterological symptoms of GERD.

Conclusions: The incidence of GERD in children with persistent upper respiratory diseases was high (35\%) in our group, but not as high as has been previously assessed. More than 1/3 of reflux episodes were non-acid. Reflux should be taken into consideration as a probable etiology of persistent upper respiratory diseases in children. $24-\mathrm{h} \mathrm{pH}$ and impedance monitoring is a more precise way of diagnosing GERD than classic $\mathrm{pH}$-metry.

Key words: upper respiratory diseases $\bullet$ children $\bullet$ acid reflux $\bullet$ non-acid reflux $\bullet$ extra-esophageal reflux

ПОСТОЯННЫЕ РЕСПИРАТОРНЫЕ ЗАБОЛЕВАНИЯ ВЕРХНИХ

ДЫХАТЕЛЬНЫХ ПУТЕЙ У ДЕТЕЙ: РОЛЬ ГАСТРОЭЗОФАГЕАЛЬНОГО

РЕФЛЮКСА, ИЗУЧЕННОГО С ИСПОЛЬЗОВАНИЕМ ВНУТРИПРОСВЕТНОГО ИМПЕДАНСА И РН-МЕТРИИ

\section{Резюме}

Введение: Множество признаков и симптомов оториноларингологических жалоб было приписано болезни гастроэзофагеального рефлюкса (ГЕРБ). Однако, не представлено точных доказательств такой закономерности. Недавние исследования предполагают, что в некоторых случаях ГЕРБ может быть связан с респираторными заболеваниями верхних дыхательных путей у детей. Представленая работа исследует данную связь. Цель исследования состояла в том, чтобы оценить уровень ГЕРБ среди детей с постоянными респираторными заболеваниями верхних дыхательных путей, помещая электрод в пищевод. Рефлюкс может быть обнаружен в виде изменений внутриполостного давления, являющегося результатом появления жидкости в пищеводе, а рН-метрия может быть использована для классифицикации рефлюкса как кислого или некислого. 
Материал и методы: Данное исследование было проведено в нескольких центрах. В нем участвовали дети (411,5 лет) с постоянными респираторными заболеваниеми верхних дыхательных путей. Были исключены хронические болезни, такие как аллергия, астма, муковисцедоз и врожденные аномалии. Одним ларингологом был поставлен диагноз хронической болезни верхнего трактата. Все дети подверглись 24-часовому многоканальному внутрипросветному импедансу и рН-метрии (MII-pH). Диагноз ГЕРБ был поставлен аналитическим программным обеспечением BioVIEW после того, как один исследователь провел проверку.

Результаты: В исследовании участвовало 31 пациент (17 мальчиков, 14 девочек, средний возраст 6,8 лет). Диагноз ГЕРБ был поставлен у 11/31 (35\%) пациентов. В общей сложности было обнаружено 1172 рефлюксов с помощью MII-pH, при этом 759 (65\%) из них были кислотные, 413 (35\%) были некислотные. Наиболее распространенные признаки это - дыхание через рот (28/31), храп (22/31), неприятный запах (13/31), откашливание (4/11) и одышка (2/11). Ни один из пациентов не указал гастроэнтерологических признаков ГЕРБ.

Заключения: Частота появления ГЕРБ у детей с постоянными респираторными заболеваниями верхних дыхательных путей была высокой (35\%) в нашей группе, но не настолько высокой как ранее предполагалось. Больше 1/3 случаев рефлюкса были некислотными. Рефлюкс должен быть рассмотрен как признак вероятной этиологии постоянных респираторных заболеваний верхних дыхательных путей у детей. 24-х часовой контроль с помощью рН-метрии и импеданса является более точным способом диагностики ГЕРБ, чем классическая рН-метрия.

Ключевые слова: респираторные заболевания верхних дыхательных путей • дети • кислотный рефлюкс • некислотный рефлюкс • экстраэзофагеальный рефлюкс

\section{PERSISTENTES ENFERMEDADES DE VÍAS RESPIRATORIAS ALTAS EN NIÑOS: PAPEL DE REFLUJO GASTROESOFAGICO ESTUDIADO USANDO IMPEDANCIA INTRALUMINAL Y PH}

\section{Extracto}

Introducción: Una variedad de signos y síntomas de quejas otolaringologicas han sido atribuidos a la enfermedad de reflujo gastroesofagico (GERD). Sin embargo, la prueba de tal asociación no está presentada. Los estudios recientes sugieren que en algunos casos GERD puede estar relacionado con enfermedades de vías respiratorias altas en niños, y este estudio explora la conexión. El objetivo del estudio era estimar el frecuencia de GERD entre niños con la persistente enfermedad de vías respiratorias altas insertando un electrodo en el esófago. El reflujo puede ser descubierto como cambios de la resistencia intraluminal provocada por el líquido dentro del esófago, y las medidas de $\mathrm{pH}$ pueden ser usadas para clasificar el reflujo como ácido o no ácido.

Material y Métodos: El estudio tuvo lugar en muchos centros. Participaron los niños (4-11,5 años) con la persistente enfermedad de vías respiratorias altas. Las enfermedades crónicas, como alergia, asma, fibrosis quística, o anomalías congénitas fueron excluidas. El diagnóstico de la enfermedad respiratoria crónica fue hecho por un laringólogo. Todos los niños se sometieron a una impedancia intraluminal multicanal y pH estudio (MII-pH) de 24 horas. El diagnóstico de GERD fue hecho con el software de análisis BioVIEW después de la revisión manual por un investigador.

Resultados: Exactamente 31 pacientes consecutivos (17 muchachos, 14 muchachas, edad media 6,8 años) fueron matriculados en el estudio. Un diagnóstico de GERD fue hecho en el 11/31 (35\%) pacientes. Un total de 1172 episodios de reflujo fue descubierto por el MII-pH, y el 759 (65\%) de ellos eran ácidos, el 413 (el 35\%) no eran ácidos. Los síntomas más comunes eran respiración por la boca (28/31), ronquido (22/31), olor malo(13/31), tos (4/11), y ahoguío (2/11). Ninguno de los pacientes declaró síntomas gastroenterológicas de GERD.

Conclusiones: La frecuencia de GERD en niños con enfermedades de vías respiratorias altas era alta (35\%) en nuestro grupo, pero no tan alta como ha sido creido antes. Más que 1/3 de los episodios del reflujo no eran ácidos. El reflujo debería ser tenido en cuenta como una etiología probable de persistentes enfermedades de vías respiratorias altas en niños. Las 24 horas de pH y impedancia son un modo más preciso de diagnosticar a GERD que el pH-metría clásica.

Palabras claves: enfermedades de vías respiratorias altas • niños • reflujo ácido • reflujo no ácido • reflujo extraesofágico

\section{Background}

The child who is "always sick" is a common problem for different medical specialists. The diagnosis and management of persistent respiratory tract infection in children presents a significant challenge for doctors. An increasing number of studies have indicated that gastroesophageal reflux disease (GERD) could be related to various extra-esophageal disorders such as chronic sinusitis, otitis media with effusion, chronic cough, and, recently, adenoid and 
tonsil hyperplasia and persistent upper respiratory disease [1]. Laryngologists may find extra esophageal symptoms and signs in children with GERD. In children with laryngeal symptoms, the prevalence of GERD is unknown, but may be more than $60 \%[2,3]$. Because of the proximity of the trachea to the esophagus, the respiratory tract is vulnerable to the effects of GERD. Upper respiratory disease often coexists with adenoids and tonsil hypertrophy in children. The most common symptoms of adenoid hyperplasia include snoring, nasal congestion/mouth breathing, noisy breathing, rhinorrhea, recurrent otitis media, and sleep disturbance. In children, the true incidence of adenoid hyperplasia is difficult to assess, but it seems to occur in $11 \%$ of symptomatic school children [4].

Although the role of gastric refluxate in the development of upper tract diseases is still unknown, we do know that acid exposure results in edema and secretion in respiratory mucosa [5]. Moreover, minimal but chronic acid exposure can turn a minor laryngeal injury into subglottic stenosis [6].

So far there is limited data to confirm the relationship between the presence of refluxate in the pharynx or larynx and extra-esophageal symptoms of GERD, and lack of a proper diagnostic tool could play a part. Until now, studies have detected only those reflux episodes with $\mathrm{pH}<4$, but it is possible that not only acidic but also alkaline and neutral reflux episodes are responsible for irritation and hypertrophy of mucosal tissuses[7,8]. There is evidence that infants and children have a much higher proportion of reflux, but of the non-acidic type that cannot be detected by classic $\mathrm{pH}$-monitoring [9]. Monitoring of the esophagus with a $\mathrm{pH}$ probe has been the gold standard for measuring acid reflux, but it has the major limitation that it cannot detect nonacid reflux, and this might underlie some extra-esophageal symptoms of GERD. Moreover, even use of dual probe $\mathrm{pH}$ monitoring does not allow measurement of reflux episodes with $\mathrm{pH}$ above 4.0 or the actual upward extent of the bolus.

Combined multiple intraluminal impedance (MII) and $\mathrm{pH}$-monitoring is a relatively new technology that provides a more detailed description of esophageal events: it detects acid and non-acid reflux episodes and measures the upward extent of the bolus and its physical length. Many consider it the new gold standard for evaluation of GERD in adults[10].

The aim of this study was to assess the prevalence of gastroesophageal reflux disease in children with persistent upper tract infection by using the combination of MII and $\mathrm{pH}$-monitoring.

\section{Material and Methods}

Exactly 31 children (17 males and 14 females) with a mean age of 6.8 years (range 4 to 11.5 years) with respiratory symptoms were examined by a single laryngologist at the Institute of Physiology and Pathology of Hearing, Kajetany, Poland and chosen for further diagnosis by a gastrologist. Patients with persistent, recurrent upper respiratory tract infections (more the 10 episodes per year) were referred to the Department of Pediatric Gastroenterology and Nutrition, Medical University of Warsaw for evaluation of GERD. Excluded were children with congenital

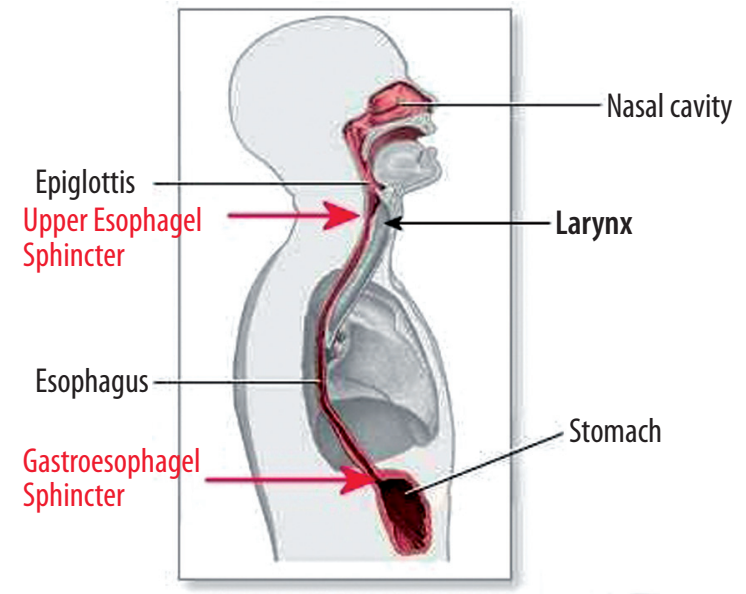

Figure 1. Oesophagus.

anomalies, allergy, systemic diseases (including diabetes), leukemia, and malnutrition; similarly, they were excluded if they had received in the previous 2 weeks drugs that might affect motor function of the gastrointestinal tract or might reduce gastric acid production (i.e. $\mathrm{H}_{2}$-receptor antagonists, proton pump inhibitors, antacids, cisapride, metoclopramide, theophylline, anticholinergic, neuroleptics, and sucralfate) (Figure 1).

To evaluate GERD, 24-hour multichannel pH/impedance was performed with an appropriate-to-age catheter (Sandhill Scientific Inc., Denver, CO, USA). The pH/impedance catheter consisted of a $2.3 \mathrm{~mm}$ polyurethane catheter incorporating 6 impedance segments (each $2 \mathrm{~cm}$ long) and a $\mathrm{pH}$-measuring electrode. The configuration of this catheter allowed changes in intraluminal impedance at 3 , $5,7,9,15$, and $17 \mathrm{~cm}$ above the lower esophageal sphincter (LES) to be recorded. In addition, $\mathrm{pH}$ was monitored at $5 \mathrm{~cm}$ above the LES. The $\mathrm{pH}$ sensor was placed at the level of the third vertebra above the diaphragm, a location determined from an X-ray. The data were collected by a Sleuth mobile recorder (Sandhill Scientific) (Figure 2).

Parents were asked to register any symptoms present during study, sleep, and meals using event marker keys on the recorder and to note them on a paper form. There were no diet restrictions during the study. Data were analysed by BioVIEW analysis software (ver. 5.4.3) and reviewed manually by a single investigator. Meal periods were excluded from the analysis. All reflux events were classified in three ways: as "pH/MII acid" when retrograde bolus movement was detected by an impedance drop and accompanied by a $\mathrm{pH}$ drop from above 4.0 to below; "pH/MII nonacid" when there was no $\mathrm{pH}$ drop during the impedance-detected retrograde bolus movement; and " $\mathrm{pH}$ only" if a $\mathrm{pH}$ drop from above 4.0 to below was observed for at least 5 seconds regardless of retrograde bolus movement. Gas, liquid, or mixed reflux events could also be distinguished by MII. A symptom was considered as related to the reflux event if, in terms of the $\mathrm{pH}$-impedance trace, it occurred within a 2-minute window.

Abnormality was scored if any of the normal values set out in the study report by DeMeester was exceeded. The DeMeester score was obtained from 6 different 


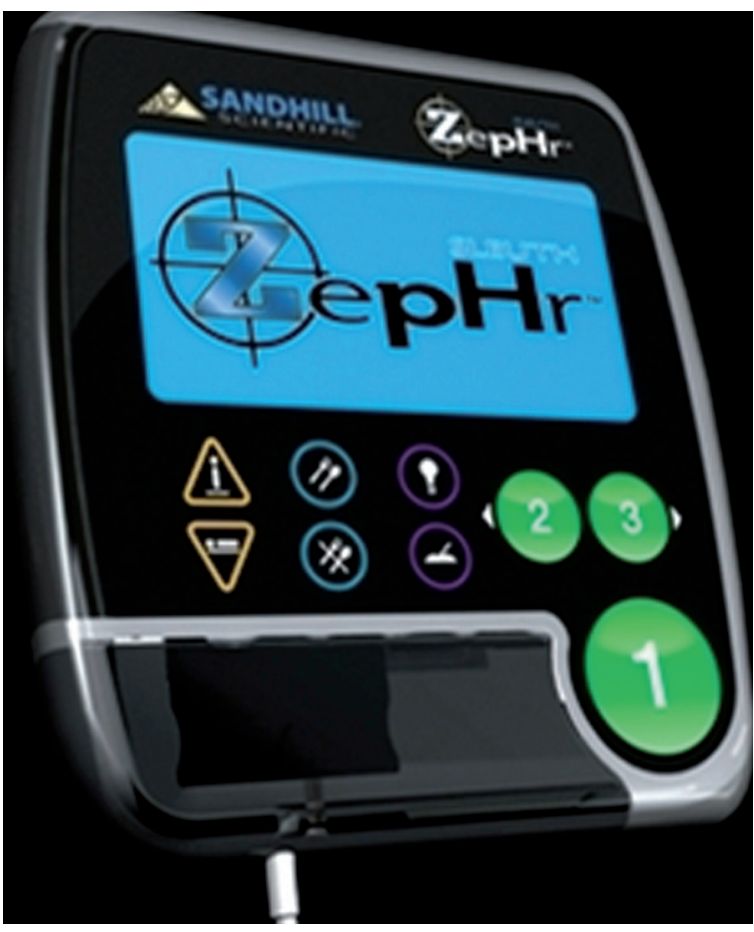

Figure 2. $\mathrm{pH}$ and impedance: combined multiple intraluminal impedance (MII) and 24-hour pH monitoring.

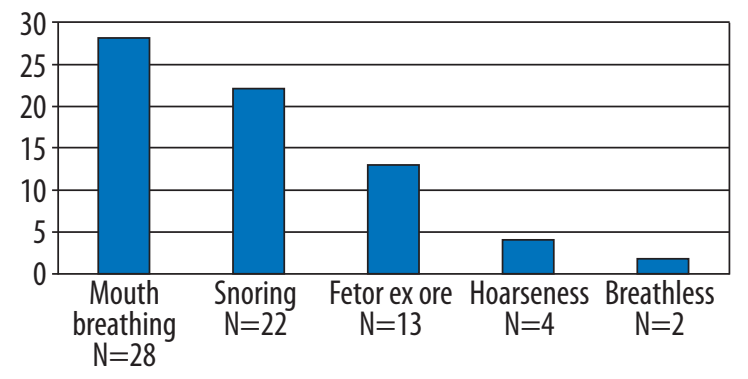

Figure 3. Symptoms index in the examined group of 31 children.

parameters: (1) total percentage time $\mathrm{pH}<4.0$; (2) percentage time $\mathrm{pH}<4.0$ in the upright period; (3) percentage time $\mathrm{pH}<4.0$ in the recumbent period; (4) the total number of acid reflux episodes; (5) the total number of acid reflux episodes longer than 5 minutes; and (6) the duration of the longest acid reflux episode. Mean values and SD were calculated.

The study design was approved by the Bioethical Committee of the Medical University of Warsaw. For all patients written informed consent was obtained from at least one parent.

\section{Results}

Of the 31 subjects in the study, all had more than $10 \mathrm{ep}$ isodes of recurrent respiratory tract infection (Figure 3 ).

The amount of upper respiratory tract infection (URTI) in the examination group, including nasopharyngitis, pharyngitis, tonsillitis, sinusitis, laryngitis, and otitis media, are described in Table 1.
Table 1. Frequency of upper respiratory tract infection (URTI) in the examined group of 31 children.

\begin{tabular}{ccc}
\hline URTI & Amount $[\%](\mathbf{n = 3 1 )}$ \\
\hline Nasopharyngitis & 21 & {$[68 \%]$} \\
\hline Pharyngitis & 16 & {$[52 \%]$} \\
\hline Tonsillitis & 15 & {$[48 \%]$} \\
\hline Sinusitis & 7 & {$[23 \%]$} \\
\hline Laryngitis & 6 & {$[19 \%]$} \\
\hline Otitis media & 18 & {$[58 \%]$} \\
\hline
\end{tabular}

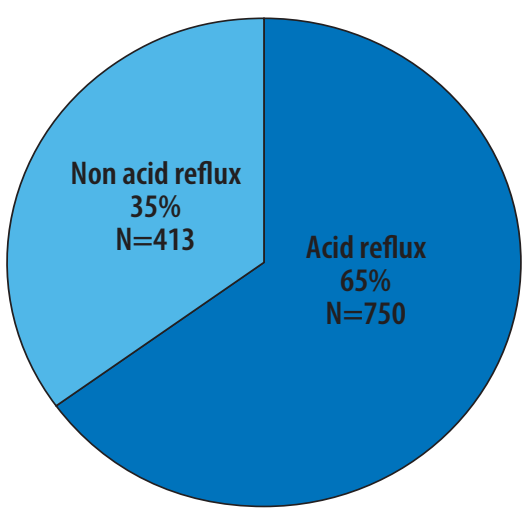

Figure 4. Episodes of gastro-oesopageal reflux $\mathrm{N}=1172$.

Gastroesophageal reflux was diagnosed in 11 (35\%) children. There were a total of 1172 reflux events (RE) detected by $\mathrm{pH} / \mathrm{impedance}$, and of these 413 (35\%) were characterised as non-acid and 759 (65\%) as acid (Figure 4).

1242 reflux events were detected by $\mathrm{pH}$ alone. Only $45.5 \%$ of all reflux events (70.2\% of acid RE) found after $\mathrm{pH} / \mathrm{im}$ pedance trace analysis were also detected by $\mathrm{pH}$-only analysis. During the 24-hour $\mathrm{pH} /$ impedance monitoring no symptoms were recorded by patients and/or their parents. Evaluation of the relationship between the character of a reflux event and its proximal height revealed that gas reflux events had approximately equal frequency of reaching either the medium or high esophageal zone.

\section{Discussion}

In this study we have shown that $\mathrm{pH} / \mathrm{impedance}$ is a good tool in establishing an association between respiratory symptoms and gastroesophageal reflux in treated children with persistent symptoms. The results of our pilot trial demonstrate that in our examination group the prevalence of GERD in children with persistent upper respiratory diseases is 35\%.

In two pediatric prospective studies, Keles et al. [11] and Tumgor et al. [12] determined the incidence of GERD as $66.7 \%(20 / 30)$ and 56.7 (17/30) respectively; mean age of the patients was 6.5 years and 7.9 years, respectively. In both studies, 24-hour $\mathrm{pH}$ monitoring with a dual probe was used. 24-hour $\mathrm{pH}$-monitoring with two electrodes on the catheter allows monitoring of the $\mathrm{pH}$ at the level of $5 \mathrm{~cm}$ (distal) 
and $20 \mathrm{~cm}$ (proximal) above LES, but it still can register only acid reflux episodes. The lack of normative values and methodological variability in proximal esophageal $\mathrm{pH}$ measurements, especially related to the positioning of the upper $\mathrm{pH}$ probe, make interpretation of proximal $\mathrm{pH}$ data difficult [13]. Moreover, proximal $\mathrm{pH}$-metry cannot provide any information on causality between refluxed gastric acid and symptoms, which was demonstrated previously in adults with laryngopharyngeal reflux disease [14]. Regarding unproven clinical utility of proximal $\mathrm{pH}$ monitoring, there is a need for more sensitive and accurate techniques for defining proximal reflux in the esophagus. The 24-hour $\mathrm{pH} / \mathrm{im}$ pedance monitoring is "the procedure of choice" in upper airway symptoms of GERD, because of its potential ability to detect acid and non-acid episodes of reflux and to differentiate between reflux episodes and acts of swallowing.

We reviewed studies assessing extraesophageal symptoms of GERD and we found our results similar to those of Lee et al. [15] (37.8\% of their patients with laryngopharyngeal symptoms had GERD). Considering patients suffering from atypical symptoms of GERD, Bajbouj et al. [16] determined pathologic GERD in $61 \%$ of patients. Several factors could explain the difference between the results. Firstly, different extra-esophageal symptoms were assessed. A second possible reason is the difference between "pediatric" and "adult" GERD. Finally, in Asian countries the prevalence of GERD seems to be lower than in Western countries.

In our study, acid reflux episodes represented $2 / 3$ of all reflux episodes, while in patients without GERD the proportion of acid and non-acid is equal. It seems that non-acid

\section{References:}

reflux episodes are less frequency than acid refluxes, although non-acid refluxes may also play a role in the pathogenesis of persistent respiratory disease. However, similar findings were noted previously in studies that assessed other protracting extraesophageal symptoms of GERD recurrent sinusitis, otitis, or hoarseness [17].

A limitation of the trial is a lack of a control group, but it is very difficult to perform $\mathrm{pH} /$ impedance monitoring in a group of healthy children. This is why there are no normal values for different age groups both for $\mathrm{pH}$-monitoring alone or combined with impedance.

Despite treatment with antisecretory agents such as proton pump inhibitors, many patients continue to have respiratory symptoms that could be ascribed to GERD. The use of $\mathrm{pH} /$ impedance is a new tool in the evaluation of pediatric GERD. This measurement may give new insight into the pathophysiology of GERD. It is able to give information about acid and non-acid reflux, which should be useful in choosing treatments.

\section{Conclusions}

The incidence of gastroesophageal reflux disease in children with persistent upper respiratory diseases was high (35\%) in our examination group, but it was not as high as has been previously assessed. More than $1 / 3$ of reflux episodes were non-acid. Reflux should be taken into consideration as a probable etiology of persistent upper respiratory diseases in children. In diagnosing GERD, 24-h pH/impedance is a more precise technique than classic $\mathrm{pH}$-metry.
1. Boyle JT: Gastroesophageal reflux in the pediatric patient. Gastroenterol Clin N Am, 1989; 18: 315-33

2. Keles B, Ozturk K, Arbag H et al: Frequency of pharyngeal reflux in children with adenoid hyperplasia. Int J Pediatric Otorhinolaryngology, 2005; 69: 1103-7

3. Tolia V, Vandenplas Y: Systemic review: the extra-oesophageal symptoms of gastro-oesophageal reflux disease in children. Aliment Pharmacol Ther, 2009; 29: 258-72

4. Kara CO, Ergin H, Kocak G et al: Prevalence of tonsillar hypertrophy and associated oropharyngeal symptoms in primary school children in Denizli, Turkey. Int J Pediatric Otorhinolaryngology, 2002; 66(2): 175-79

5. Ulualp SO, Toohill RJ, Hoffmann R, Shaker R: Pharyngeal pH monitoring in patients with posterior laryngitis. Otolaryngology Head Neck Surg, 1999; 120: 672-77

6. Little FB, Koufman JA, Kohut RI, Marshall RB: Effect of gastric acid on the pathogenesis of subglottic stenosis. Ann Otol Rhinol Laryngol, 1985; 94: 516-19

7. Harris PK, Hussey DJ, Watson DI et al: Reflux changes in adenoidal hyperplasia: a controlled prospective study to investigate its etiology. Clin Otolaryngol, 2009; 34: 120-26

8. Stapleton A, Brodsky L: Extra-esophageal acid reflux induced adenotonsillar hyperplasia: case report and literature review. Int J Pediatr Otorhinolaryngol, 2008; 72: 409-13

9. Wenzl TG, Moroder C, Trachterna $\mathrm{M}$ et al: Esophageal $\mathrm{pH}$ monitoring and impedance measurement: a comparison of two diagnostic tests for gastroesophageal reflux. J Pediatr Gastroenterol Nutr, 2002; 34: 519-23
10. The Montreal definition and classification of gastroesophageal reflux disease: a global evidence-based consensus. Am J Gastroenterol, 2006; 101: 1900-20

11. Keles B, Ozturk K, Arbag H et al: Frequency of pharyngeal reflux in children with adenoid hyperplasia. Int J Pediatr Otorhinolaryngol, 2005; 69: 1103-7

12. Tumgor G, Midilli R, Yuksekkaya HA et al: Laryngopharengeal reflux in patients with severe adeno-tonsil hyperplasia. Int J Pediatr Otorhinolaryngol, 2006; 70: 761-62

13. Ceccatelli P, Mariottini M, Agnolucci A et al: Acid exposure of proximal esophagus in healthy subjects. Minerva Gastroenterol Dietol, 1998; 44: 129-34

14. Bove MJ, Rosen C: Diagnosis and management of laryngopharyngeal reflux disease. Cur Opin Otolaryngol Head Neck Surg, 2006; 14: 116-23

15. Lee BE, Kim GH, Ryu DY et al: Combined dual channel impedance/pH-metry in patients with suspected laryngopharyngeal reflux. J Neurogastroenterol Motil, 2010; 16: 157-65

16. Bajbouj M, Becker V, Neuber M et al: Combined pH-metry/ impedance monitoring increases the diagnostic yield in patients with atypical gastroesophageal reflux symptoms. Digestion, 2007; 76: 223-28

17. Lee BE, Kim GH, Ryu DY et al: Combined Dual Channel Impedance/pH-metry in Patients With Suspected Laryngopharyngeal Reflux. J Neurogastroenterol Motil, 2010; 16: $157-65$ 